\title{
WASTE MANAGEMENT AS AN ELEMENT OF THE CREATION OF A CLOSED LOOP OF SUPPLY CHAINS ON THE EXAMPLE OF MINING AND EXTRACTIVE INDUSTRY
}

\author{
Joanna DYCZKOWSKA \\ Koszalin University of Technology \\ Yuliia BULHAKOVA \\ Poznan University of Economics and Business \\ Zygmunt ŁUKASZCZYK \\ Silesian University of Technology \\ Anna MARYNIAK \\ Poznan University of Economics and Business
}

\begin{abstract}
:
The purpose of the study is presentation of the method of increasing the competitiveness of the mining industry through the demonstration of the possibility and potential in closing the loop of supply chains through waste management. A critical analysis of the source literature and an arithmetic analysis of statistical data in static and dynamic perspectives were accepted to be the research method. It has been found that the structure of the level of mining wastes and the level of their recovery rates demonstrate a large potential of closing the loop of chains in this industry and, at the same time, a potential to extend the chains through directing the material from recovery to various sectors. This constitutes an example of the direction of activities that are in line with the EU strategies for the economies of other states which possess this type wastes.
\end{abstract}

Key words: closed loop of supply chain, mining, sustainable supply chain, wastes

\section{INTRODUCTION}

Nowadays, In the context of more and more frequently appearing claims that the global energy system is evolving from a system based mainly on fossil fuels towards a system based chiefly on renewable energy sources [35], an indication of those examples which close loops in the mining industry is significant. This is particularly important for those markets which are abundant in fossil fuels, and for which the labor market connected with this is very important. According to the "Carbon Tracker" analysts [35], the costs of solar energy, wind and batteries are dropping quickly enough for them to compete with fossil fuels without any necessity of subsidies. Furthermore, it is emphasized that emerging markets and markets based on conventional energy sources readily use the possibilities offered by renewable energy sources. In the light of the above, in this study, as its goal, a presentation is accepted of a method to increase the competitiveness of the mining industry through the demonstration of the possibilities and potential in closing of the loops of supply chains through waste management. This is important because opinions on the social responsibility of mining industry are divided [26].

Scientific literature is dominated by analyzes of modern waste management technology, including flotation waste. However, in some countries still appear problems of managing waste heaps. With post-mining waste coming from the time when technology was not as advanced as modern times. Multi-ton heaps are a current environmental problem, that has not been comprehensively solved. Closing the mining loops of the delivery chains is not necessarily the only solution, because the composition of older waste is different. Focusing only on current waste management solutions dictated by modern technology is a misunderstanding.

\section{MATERIALS}

The discussions connected with close-loop supply chains are conducted within a wide context, taking into account the flows up and down the supply chain (surveys in closedloop supply chains) or in a narrower context, in which main emphasis is placed on down-up flows in supply chains (surveys in reverse logistics). Considering a different 
classification, one may state that such reflections concern a sustainable supply chain, or only one of its dimensions the pro-environmental one. Following research works from all four thematic areas [19], one may notice that particular contents overlap and have common parts.

The studies concern strategic aspects (including, designing supply chains, placing particular links, building the brand of supply chains), logistics aspects (relating to the role of logistics operators, warehousing and transport processes as well as stocks management), particular spheres of flow within supply chains (eco-design, supply, production, distribution, return flows) as well as particular issues connected with reverse logistics (reuse, refurbishing, remanufacturing, recycling, landfill). What's more, the following issues are evaluated with regard to their influence on closing the supply chain loop:

- particular management concepts (e.g. Just in Time),

- technologies which facilitate flow processes (e.g. RFID),

- legislation (e.g. the directive on waste electrical and electronic equipment - WEEE),

- 4.0 economy (e.g. the Internet of things),

- globalization of activities (e.g. extending supply chains),

- virtualization (e.g. needs regarding the increase in supply chain flexibility).

The review works show the whole spectrum of various issues both in the problematic and methodological context $[6,7,27,40]$ In the overview works, a full range of various issues, both in the problem and methodological contexts, are presented. All of the mentioned modules are mainly shown on the examples of selected industries. The considerations concern electric home appliances [56], apparel [30], automotive [2, 34], carpets [38], photocopiers [40], electrical and electronic industries [12], textile industry [26], machinery industry [45], fashion industry [28], gold industry [39], traditional retailers and online e-tailers [49]. On the basis of the analyses of studies in the area of the closed loop of the supply chain, it can be found that there is a research gap in the studies concerning the mining industry. This is probably the result among others of limited scientific literature that presents the mining industry from the perspective of supply chains. The publications available in this thematic area comprise the basic components of Osborne, Smith and Mann mining chains [8], production strategies [29], transport [5, 13, 53]. Allocation of storage area [44], KPI indicators [51]. In turn, in these positions where references are made to pro-environmental aspects $[41,55]$, there are no references to the issues of the closed loop of the supply chain, or these references are treated in a marginal manner [31].

In the present study, efforts are made to present the methods of the creation of the closed loop on the example of the mining industry. At the same time, this corresponds well with the issue of the directions related to the optimization of the management of wastes from hard coal mining, which includes a reduction of wastes through designing and optimization of the technologies used of gold excavation, neutralization of wastes on landfill sites and the recovery of wastes in mines underground and over ground [25].

This fuel, in the entire process from mining through combustion to the use of energy included in it, poses numerous problems connected with environmental protection requirements. Therefore, in this area, standards are becoming more and more rigorous in the European Union; new regulations and obligations are accepted for particular states to undertake further efforts aimed at an achievement of sustainable, law-carbon economy. Each year, the European Union produces tons of mining wastes which are stored on heaps, which change their usefulness under the influence of physical and chemical properties $[32,37]$. For this reason, addressing the issue of the creation of a closed loop in the industry in question is valid and important.

\section{METHODS}

On the grounds of the present state of knowledge, and a study of the source literature, the following assumption is accepted:

$\mathrm{H} 1$ level of the resources of mining wastes in the structure of industrial wastes and the level of their recovery rates demonstrates a large and still unused potential to create the closed loops of supply chains in the context of the possibilities which are provided by the exemplary practices of those entities that are engaged in their recovery.

The analysis focuses on the Polish market; nevertheless, the implications are of a universal nature and can be referred to any economy where mining wastes occur.

The theoretical part concerning closed supply chains was primarily based on an analysis of materials reviewed included in scientific databases and legal documents. The items were searched using the following key words: closed supply chain, closed supply chain/mining and quarrying, closed supply chain/coal supply chain, closed supply chain/coal industry; closed supply chain/mine industry.

The section related to energy sources and the Polish mining industry was mainly based on statistical resources, reports and on the internal materials of a company that specializes in the recovery of materials from mining wastes.

A critical analysis of the source literature and an arithmetic analysis of statistical data in static and dynamic perspectives were accepted to be the research method.

The time range of the analyses was dictated by the availability of data. The latest data related to the Polish market in the scope of waste levels comes from the year 2017. The Central Statistical Office has been introducing this data since the year 2012 only. The review of the literature on the subject of the closed loop of the supply chain concerned the latest items.

The object of the research on the case study level includes coal mining wastes from preparatory works and from the exploitation of coal deposits, wastes from the process of coal enrichment, as well as fine-grained and post-flotation wastes. These are wastes with granulation up to $250 \mathrm{~mm}$. A detailed catalogue of coal mining wastes is contained in the Ordinance by the Minister of Environment in Section 01 [52]. 
LEVEL OF WASTES IN THE POLISH MINING AND COAL INDUSTRIES COMPARED TO THE EU RESOURCES: RESEARCH RESULTS

In numerous documents related to the energy policy of the European Union [14, 15, 16, 24] and in documents concerning the individual economies [33, 43, 46, 47], attention is drawn to the need to raise environmental efficiency in the process of the exploitation of deposits and their transfer to subsequent links. Maintaining an added value of products for as long as possible and processing of wastes will permit the creation of socially responsible chains, which will contribute to the improved social welfare and the quality of the environment.

This is important in the context of the increasing role of non-conventional energy sources and the declining level of the use of fossil fuels (Figure 1).

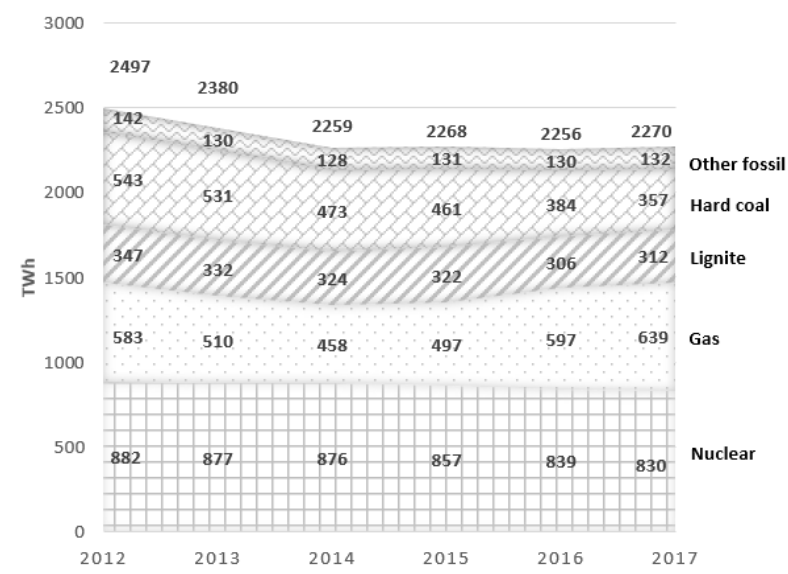

Fig. 1 Level of the use of energy sources in the European Union Member States

Source: own study based on [10].

It is predicted that in the coming years, the share of conventional energy sources will be diminishing, especially as a result of the plans concerning withdrawal of coal as an energy source. For example, the Netherlands and Portugal have undertaken to withdraw all their coal power stations by the year 2030, Italy and Great Britain and Austria have undertaken to close coal power stations by the year 2025, while France and Sweden by the year 2023. In some states, such as Germany and Slovakia, this issue is being widely discussed.

There are, however, many states, such as Poland, where the richness of fossil fuels justifies their use to a large extent. As it is evidenced by the report, in the previous year in Poland, $47 \%$ of electricity was produced from hard coal, $31 \%$ from lignite coal; wind sources provided $8 \%$ of electricity, biomass sources: $6 \%$, gaseous sources: $4 \%$, other sources: $3 \%$, and hydro power plants: $1 \%$. An acquisition of raw materials for energies from traditional sources in the convention of the creation of closed loops in supply chains through waste processing and management offers an opportunity for the perception of the mining industry as one that is more environment friendly. This concerns both wastes produced from the mining industry, e.g. from rinsing and purification of minerals as well as wastes from power industry, e.g. volatile coal ashes. It is important to conduct assessments of fuels not only in terms of their energy properties (e.g. combustion heat), economic properties (e.g. the acquiring cost of fuels), social properties (e.g. the impact of the mining economy on the level of employment and the development of industries related to mining), but also in terms of a widely understood environmental value (both related to the basic product and its ecological variants as well as to the waste management degree). This policy is in line with EU guidelines.

Directive 2006/21/EC on the management of waste from extractive industries provides for means, procedures and guidelines aimed at the prevention or minimization of negative environmental impacts and threats to human health resulting from the management of wastes from mining industry. Frameworks have been developed to ensure a structured base for the assessment of the results achieved by the EU Member States in relation to the implementation of the Directive and specific provisions. In July 2017, the Commission requested the adequate interested parties in the mining industry in the Member States, such as public authorities responsible for the mining industry, non-government organizations dealing with environmental protection and the civil society to contribute their knowledge and experience to jointly form the following [17]:

- guidelines related to the development of the Extractive Waste Management Plan (EWMP): a plan of waste extraction),

- example Extractive Waste Management Plans (EWMP),

- meetings to investigate the aspects of close circuit economy within the frameworks of EWMP.

What is of significance is that the request also concerned the creation of a set of the best practices (from among of which four mines including two Polish mines: Jastrzębska Coal Company and Bogdanka Mine have already been selected). The role of the Polish entities in the creation of exemplary behaviors is also appreciated on the EU level. In Poland, according to the latest data available, mining and extraction wastes constitute over a half of industrial wastes: $56.5 \%$ (i.e. $63,832.2$ thousand tons compared to $110,144.6$ thousand tons). Over the past few years, their share in the whole of wastes has been growing gradually (Figure 2).

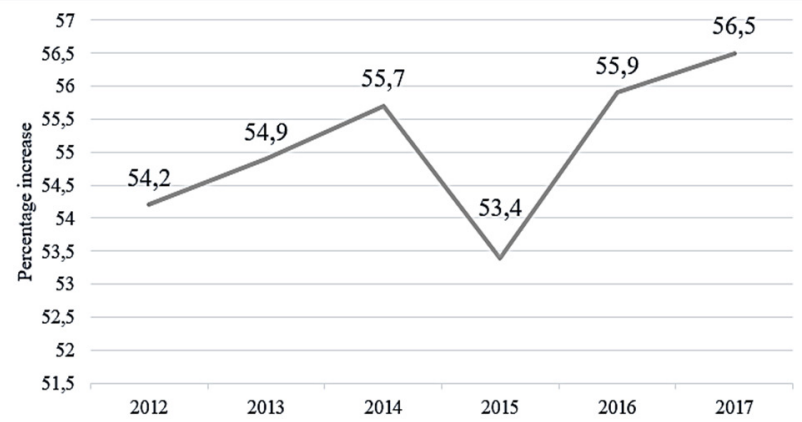

Fig. 2 Percentage share of extractive and mining wastes in industrial wastes

Source: own study based on [20, 21, 22, 23].

For this reason, closing of the loop chain of supplies in the mining industry constitutes a huge challenge and, at the same time, it offers a great potential for an improvement 
of environmental efficiency through the creation of looped chains (where materials recovered are directed to the same industry) and extended chains (by generating supplies of materials to other industries).

This potential is also expressed in the quantity of wastes that have so far been accumulated. At present, according to the latest data available, the annual growth of the quantities of mining wastes is on the level of 4 per cent (i.e. 800,529 thousand tons as compared to $769,458.1$ thousand tones) (Figure 3). Their quantity is growing (in spite of fluctuations in the individual years). In the year 2012, accepted as the starting point for the analyses, there were $791,346.9$ thousand tones.

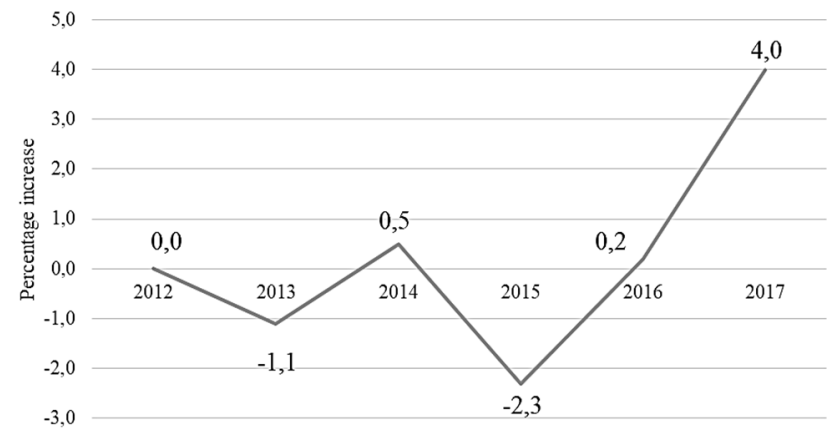

Fig. 3 Annual increment of mining wastes

Source: own study based on [20,21,22, 23].

It can be stated based on the latest data available that the recovery of mining wastes was on the level of $18.7 \%$, i.e. $11,670.6$ thousand ton as compared to $62,267.8$ thousand tons (Figure 4).
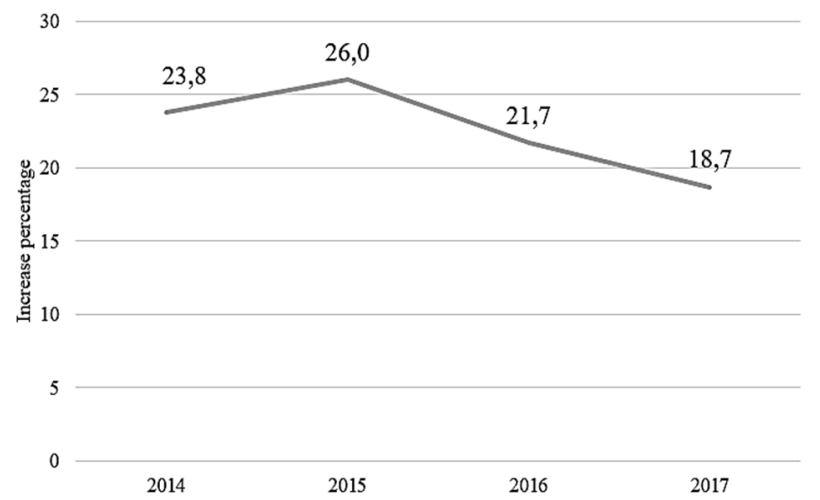

Fig. 4 Mining waste recovery level in the years of 2014-2017 Source: own study based on [20, 21, 22, 23].

According to the classification by the Central Statistical Office, recovery is related to any actions that pose no hazard to human life and health or to the natural environment that consist in the use of the whole or part of wastes, or that are aimed at a recovery of substances, materials or energy from wastes and their use.

In a dynamic perspective, its level is slightly decreasing; however, due to the requirement of the adaptation to the EU guidelines, it can be predicted that this level will be gradually growing in a long-term perspective.

A part of renewed wastes are neutralized. Neutralization of wastes according to the definition provided by the Central Statistical Office consists in wastes being the subject of the processes of biological, physical or chemical transformation in order for them to reach a state that does not pose any threats to human health or life or to the environment. Waste neutralization processes include dumping in landfills, processing in soil and in earth, surface retention (placing wastes in sedimentary fields or in lagoon) or their thermal processing.

Considering the latest data available, 11.7 per cent (7,309.4 thousand tons) of mining wastes are neutralized; a substantial part of these is dumped wastes (landfills, heaps, tailing ponds).

Wastes that are collected by other recipients are classified in statistical data as "wastes with unknown management methods" constitute the largest percentage of total wastes: almost 70 per cent $(430,003.8$ thousand tons).

Wastes that are temporarily stored (kept or collected prior to their transport, recovery or neutralization) constitute an insignificant percentage.

Recovery as a separate procedure has been singled out since 2014; for this reason, no previous data is comparable. The only numerical data that is comparable is the waste treatment level. As stated previously, this was almost 12 per cent in the year 2017, and 25.7 per cent in 2012. This may demonstrate a greater percentage of unrecorded materials that are handed over for recovery, which are contained in the group of materials classified as "collected by other recipients".

Based on an analysis of data, it is to be stated that the creation of closed loops in mining chains is important due to a large percentage of wastes produced. Merely one fifth of wastes recovered that are found in records $(11,670.6$ million ton) are included in the closed loop; nevertheless, a significant part of wastes remains unmanaged. Hence, there is a need for an increase of the recovery factor and thus for the creation of closed loop chains on a larger scale.

At the same time, this raises the demand for the development of those entities that will deal with a commercial recovery of this type materials.

\section{CREATION OF CLOSED LOOP ON THE EXAMPLE OF WA- STES FROM POLISH MINING INDUSTRY: RESEARCH RE- SULTS}

As noted previously, the Polish economy is characterized by a high level of the production of energy from fossil materials. Among the EU Member States, it holds the first position as regards the use of hard coal (Figure 5), the result being a high level of the accumulation of mining wastes.

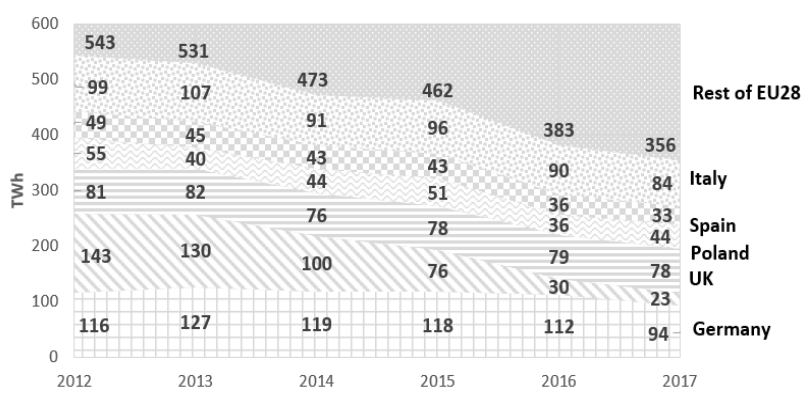

Fig. 5 Hard coal electricity generation (including split of top 5 countries)

Source: own study based on [10]. 
In the past, waste heaps used to be created near coal mines and mining shafts; these are the so-called on-site plant heaps with regular or conical shapes of above-ground types. In the recent years, heaps of this type have been avoided; instead, central dumps have been preferred. These are flat and leveling heaps, also known as above-ground heaps, which most frequently fill excavations after the exploitation of sand that is used for mining floors.

The main reason for the occurrence of heaps by coal mines was a bad economy management system, one that did not form any mechanisms to encourage enterprises to rationally use materials, including wastes. Huge quantities of waste were collected, while no one would think about their processing or enhancement. Indeed, principles were set out in relation to rational dealing with wastes according to the following hierarchy: prevention of the generation of wastes; use of those wastes that could not be avoided; neutralization of those wastes whose generation could not be avoided and that could not be utilized. Nevertheless, these principles are not meticulously observed $[11,36]$. The regulations and system solutions in the Polish economy that have so far been introduced are not adapted in all situations to the solutions accepted, and some barriers remain that restrict an effective functioning of waste management.

Modeling of a deposit and a precise characterization of a resource may result in a minimization of the extraction of undesirable and non-market materials; in this manner, mining wastes are minimized. The selection of the mining strategy depends on numerous factors, including the depth of the mineral underground, the scale of its occurrence, the characteristics and tectonics of the bedrocks, groundwater hydrology, permissible trace, the mining technology available and the human resource available. The probable characteristics of mining wastes constitutes an important parameter that is assessed when designing the mining operation. For this reason, any entity that obtains a deposit mining permit [4] is obliged to observe the norms that apply to the examination of the expected behavior and properties of the future mining wastes [33]. Owing to this, the composition can be predicted of wastes from the excavated material and from the material processing operation; it can be determined with a large degree of probability which chains the minerals recovered will go to.

Thereby, mining wastes constitute one of the final elements of the mining chain and, at the same time, the starting element in supply chains in many industries. Creation of a closed loop can be effected both through the management of mining wastes (that come directly from mining work) and tailings (from various enhancement processes of raw material extracted).

Looking at the areas of flows alone, one may find that the use of anthropogenic minerals results in a multi-directional elongation of supply chains. In particular, the movement of products is towards various industries [9]. In this manner, conventional or looped chains form. Conventional chains form in a "straight line" when the product moves from the top to the bottom of the supply chain.
Then, wastes are directed to industries connected with the production of concretes, building ceramics, cements, granular aggregate, gypsum products, road construction, production of plastics, paints, tar paper, gypsum finishes and in the direction of agriculture etc. Looped chains form when the product returns to the previous links. This is when part of recycled wastes return to the mining industry, e.g. in mining technologies (as the components of the floor that seals goaf, the components of reinforcements and mining stabilizing systems, as elements of fire protection systems) or in the reclamation process of degraded areas.

The possibilities of the use of anthropogenic minerals are assessed on various levels. For example: $100 \%$ in the construction of fills in transport systems, $50 \%$ in the production of road foundations, $35 \%$ in the production of cement, $10 \%$ in the production of mineral and asphalt mixtures, $5 \%$ in the production of concrete [9].

Therefore, there is a justification for an introduction of a closed loop of carbon chains in order to improve the level of the recovery of anthropogenic materials and to increase environmental efficiency.

In Silesia, with the largest resources of coal in Poland, there are still ca. 150 coal heaps with several million tons of waste, while there is a simultaneous increase of mining wastes on the scale of 30 to 35 million per annum. The exploitation of 1 ton of hard coal generates from 0.25 to 0.5 ton of wastes, i.e. chiefly gangue. Gangue is mainly composed of clay slates and claystone's, mudstones, sandstones and coal admixtures, which account for 20 to 25 per cent of the waste mass. From a chemical perspective, there is one more important component of the wastes: pyrite $\mathrm{FeS}_{2}$, whose participation in wastes stored is from 0.5 per cent to 3 per cent. Gangue that is kept in heaps undergoes the processes of chemical, physical and biological weathering. One of the phenomena related to the weathering of the material on heaps is pyrite oxidation. Oxidation processes lead to substantial changes in the properties of the heap material, and they have a negative environmental impact through the following [48]:

- acidification: related to a significant growth of the number of $\mathrm{H}+$ ions, which are washed out to waters in the area around the dump;

- salinisation: related to a significant growth of the number of SO42- ions, which are formed as a result of pyrite oxidation;

- thermal activity that is the result of the fact that pyrite oxidation is a strongly exothermic process.

Haldex enterprise is an entity and at the same time the major player on the Polish market which specializes in the processing and recovery of materials from mining wastes. This company provides recovery both on plant sites and outside of these. Table 1 and Figure 6 contain values in relation to these.

In the period analyzed, the largest sales volume occurred in the year 2014; after this, the level from the year 2012 returned. It is estimated that the sale volumes in the subsequent years will not change abruptly.

In the individual categories of sale, the enterprise reports 
diversified tendencies. For example, the sale of slime pellet and fines is growing sharply, while the sale of aggregates is decreasing (Figures 7 and 8).

Table 1

Processing of wastes on plant sites and management of wastes outside of plants

\begin{tabular}{|c|c|c|c|c|c|c|}
\hline $\begin{array}{l}\text { Waste processing on plant sites } \\
\text { Z1 Z2 Z6 Z10 Z12 Z18 }\end{array}$ & ָับ & $\stackrel{n}{\text { ñ }}$ & 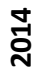 & กั่ & 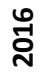 & )ิ \\
\hline $\begin{array}{l}\text { Waste processing on plant } \\
\text { sites } Z \text {, pln }\end{array}$ & 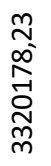 & 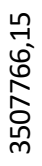 & 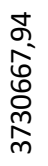 & 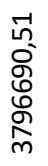 & 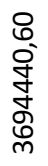 & 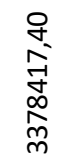 \\
\hline $\begin{array}{l}\text { Waste management outside } \\
\text { of plants, pln }\end{array}$ & 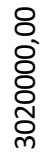 & 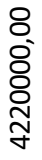 & 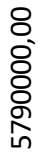 & 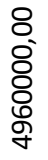 & $\begin{array}{l}8 \\
8 \\
\varnothing \\
\varnothing \\
\infty \\
\text { ษ }\end{array}$ & 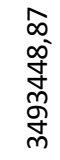 \\
\hline Total, pln & 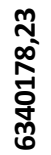 & 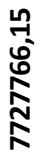 & 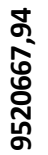 & 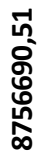 & 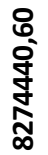 & 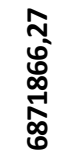 \\
\hline
\end{tabular}

Source: Internal materials of Haldex company.

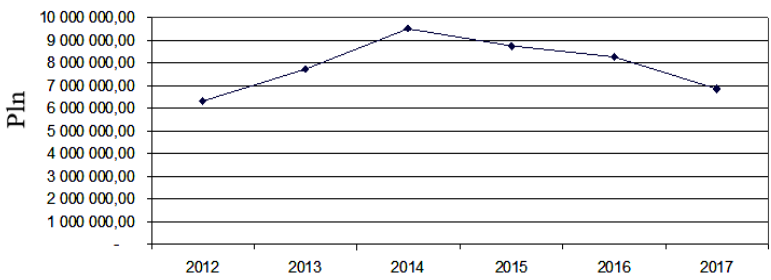

Fig. 6 Waste processing on plant sites and waste management outside of plants

Source: Internal materials of Haldex company.

The decreasing sale of aggregates is the result of among others insufficient knowledge in relation to the quality of aggregates that are adequate for specific applications and of the lack of legal regulations that would encourage entities to use wastes of this type.

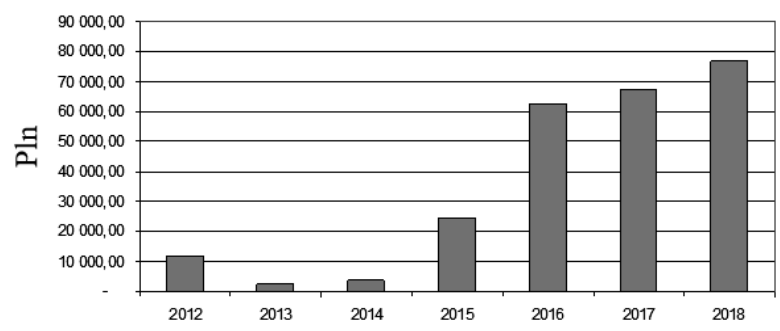

Fig. 7 Sale of slime pellet and fines

Source: Internal materials of Haldex company.

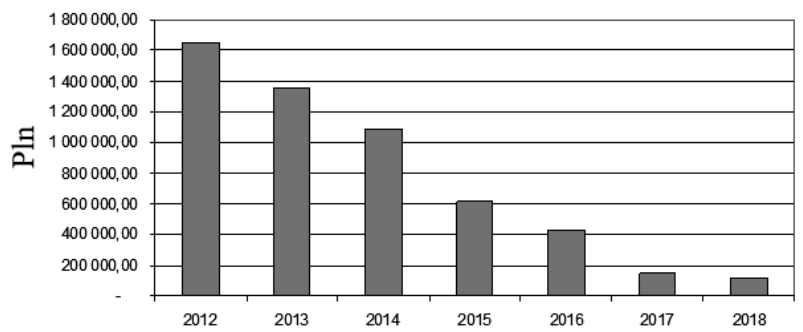

Fig. 8 Sale of aggregate

Source: Internal materials of Haldex company.
The enterprise recycles raw material, which is used in various industries. Since it appeared on the national market, the company has recycled over 180 million of mining wastes from hard coal mining.

In the waste recycling process, the company uses mining wastes from ongoing production as well as wastes from dump sites in Silesia; from these, it produces energy coal and full value aggregates, which are used as follows [3].

- engineering works (including road building);

- hydro-engineering construction (including the construction of flood embankments);

- works connected to the restoration of functionality to areas that have been degraded through human activity (including recultivation of cavities, unused opencast excavations);

- the production process of anthropogenic soil (a commercial product known as BioCarbohumus).

The newest and largest plant that processes mining wastes (in relation to the volume of wastes managed) possesses the maximum mining waste processing capacity of 525 tones per hour, which is over 1.9 million tones in a calendar year.

Table 2 presents materials recovered in the period of 2008-2017.

Table 2

Materials recovered from mining wastes in the period of 2008-2017

\begin{tabular}{|c|c|c|}
\hline $\begin{array}{c}\text { Type of waste and mate- } \\
\text { rial }\end{array}$ & $\begin{array}{c}\text { Material } \\
\text { in million tones }\end{array}$ & Percentage \\
\hline Mining waste & 180 & 100 \\
\hline $\begin{array}{l}\text { Aggregates for mining } \\
\text { works (floors) }\end{array}$ & 78 & 43.3 \\
\hline Energy coal & 20 & 11.1 \\
\hline $\begin{array}{l}\text { Aggregates for ceramic in- } \\
\text { dustry }\end{array}$ & 17 & 9.4 \\
\hline $\begin{array}{l}\text { Aggregates for engineer- } \\
\text { ing works }\end{array}$ & 13 & 7.2 \\
\hline $\begin{array}{l}\text { Material for cement in- } \\
\text { dustry }\end{array}$ & 9 & 5 \\
\hline $\begin{array}{l}\text { Mixtures based on aggre- } \\
\text { gates }\end{array}$ & 5 & 2.8 \\
\hline Light aggregates & 5 & 2.8 \\
\hline
\end{tabular}

Source: own study based on internal materials of the Haldex company.

The waste recovered constitutes over 80 per cent of the total volume. An essential part of coarse-grained or finegrained wastes from processing (from heavy liquid separators and fine jigs) as well as stone from preparatory works are used on surface in engineering construction. It is only a small percentage of fine-grained post-flotation wastes that is used underground in mines in the form of mixtures with ashes from power plants. It is to be emphasized, however, that currently wastes contain trace quantities of coal due to the use of modern coal processing technologies. From this perspective, older wastes are more attractive.

Apart from external entities, coal companies themselves deal with the recovery of coal wastes. The Polish Mining Group Joint Stock Company is an example of this, which is the largest national coal producer and it is responsible for 
nearly 50 per cent of its total production. The company possesses a production line that may annually produce ca. two million tons of full-value aggregates both from its own material and from material obtained elsewhere. Rock is crushed and sifted into three various fractions, which are used mainly in road engineering as well as engineering and construction works. For practical applications, the aggregates must fulfill standards related to the size, granulation, aspect ratio, disintegration resistance and frost resistance. If the standards are fulfilled, certification may be obtained.

To sum up, the following conclusions can be made as a result of the conducted analyses:

- there is a high percentage of extractive and mining waste in industrial waste,

- there is an increase in the extractive and mining waste,

- there is a general low level of recycling extractive and mining waste,

- there is a high level of generating energy from coal resources on the described market,

- there is a high level of recycling coal waste conducted by exemplary, specialized external entities, such as coal companies.

\section{DISCUSSION}

Industrial waste that we have inherited from the previous generations and the waste that is currently being generated, is degrading the natural environment in particular in Poland, which is chiefly based on conventional sources of energy. Without science and the most broadly understood modern technology, we will not be successful in the implementation of the industry reconstruction program in this area, which has an opportunity to become a European experimental laboratory as regards international environmental cooperation. The environmental degradation that has so far occurred is caused by insufficient knowledge and a lack of balance between energy, ecology and economics. This problem concerns other economies, as well. For this reason, the European Union has announced the following communication: "Closing the loop: EU action plan for the circular economy", while defining "circular economy as an economy where the value of products, materials and resources is maintained as long as possible, and the production of waste is minimized" [18]. In connection with this, the European Commission is currently working on guidelines and is promoting the best practices in the management plans of extractive waste EWMP.

In the light of the above and due to the high level of waste generated on the Polish market, the analyses conducted are justifiable.

Based on the work undertaken, the following may be stated:

- the considerations presented so far related to flows in the mining supply chain are poorly based on the world literature related to the closed loop of the supply chain;

- in the context of the EU energy policy and the existing rich resources on the market under discussion, there is an urgent need for the development of research related to the creation of the closed loop in mining industry.

The deposits of anthropogenic minerals have become a very attractive alternative material for manufacturers in numerous branches of industry; however, in spite of the growing scale of management, their use is still on a low level.

In the light of the above, it is justifiable to:

- create legal and fiscal conditions that would be advantageous to the building of a closed loop in mining industry,

- carry out work related to the codification and diffusion of knowledge in the area of the type and possible ways of the use of anthropogenic wastes,

- implement innovative technologies in this area,

- look for those markets and supply chains for which anthropogenic wastes could constitute an input product, including development of public procurement in this area,

- conduct research to confirm the economic and proenvironmental values of the solutions implemented,

- introduce evaluation of deposits not only related to the primary ecological properties, such as $\mathrm{CO}_{2}$ and $\mathrm{SO}_{2}$ emissions and ash content, but also from the perspective of the quality of the material to be recycled.

Due to the peculiarity of the described industry and the uncertainty with regard to shaping demand-supply policy, it is crucial to consider the validity of creating a closedloop supply chain in the context of possible market risks [50], including, in particular, the risk concerning the profitability of recycling. Due to the problem with outsourcing tasks connected with creating a closed loop, it is important to consider which entities should engage in this process [42], including, above all, whether mines or specialized external entities should deal with recycling.

\section{CONCLUSION}

The structure of industrial wastes on the Polish market justifies undertaking investments aimed at the creation of the elements of the supply chain specialized in waste recovery in the mining industry. The recovery level of wastes in this industry proves that there is a low level of their management. At the same time, those examples that demonstrate the possibility to extend supply chains through the recovery of various materials and directing these to construction, cement, ceramic, power engineering and many other industries, give grounds for one to believe that there is an unused potential for the creation of a closed loop. The scale of possible actions that is reflected in the level of unused resources and the presented possible level of recovery that is even currently achieved in the model enterprise demonstrates a gap as regards the creation of a closed loop in the mining industry and the need to pursue research in this direction.

Research analyses to be undertaken in the future could be transposed and used in other economies with a smaller participation of the industry under discussion. The Polish mining industry constitutes a perfect research field 
among others in the area in question, as the coal production volume in this sector is the largest among the European states.

\section{LIMITATIONS AND FURTHER LINES OF RESEARCH}

Due to the fact that no information has been disclosed in relation to waste management on the level of individual coal mines and that no data is available from the years preceding the year 2012, the analyses conducted are of a synthetic nature. An introduction of adequate legal regulations to oblige entities to accept greater transparency will permit a deeper scope of research in the future.

What is of a great significance in the future is an integration of research results aimed at an improvement of environmental efficiency in the entire mining chain in the area of the method of mining and transport of materials, waste management and creation of eco-friendly fuels. One of interesting research trends is the use of coal mining wastes in the production of alternative fuels. For example, finegrain wastes could be used in the production of smokeless fuel. This is because the production of smokeless fuel and fuel with a smaller fume intensity $[1,54]$ plays a double environmental role, as it causes wastes to become a profitable product that is itself environment friendly.

Furthermore, analyses of the economic feasibility of an extension and closing of chains constitutes a hugely important line of research. However, this is sensitive data that is difficult to obtain as of this day.

\section{REFERENCES}

[1] Jasiński. „Zgazowanie jako czysta technologia wykorzystania surowców zawierających węgiel," Karbo, vol. 2, pp. 6774, 2010.

[2] Jindal and K.S. Sangwan. "Evaluation of collection methods in reverse logistics by using fuzzy mathematics," Benchmark International Journal, vol. 22(3), pp. 393-410, 2015; DOI.org/10.1108/BIJ-05-2013-0062.

[3] Kledzik. "Przed nami nowe wyzwania," Ekologia, vol. 4(88), pp. 6-7, 2018.

[4] Świstak. (2017, Dec.21). Opodatkowanie wydobycia surowców naturalnych w Polsce, Warszawa: C.H. Becka. [Online]. Available: www.enggart.com/examples/students.html [Jun. 21, 2019].

[5] Zaklan, A. Cullmann, A. Neumann and C. von Hirschhausen. "The globalization of steam coal markets and the role of logistics: An empirical analysis," Journal Energy Economics, vol. 34(1), pp. 105-116, 2012.

[6] A.C. Braz, A.M. de Mello, L.A. de Vasconcelos Gomes and P.T. de Souza Nascimento. "The bullwhip effect in closedloop supply chains: A systematic literature review," Journal of Cleaner Production, vol. 202, pp. 376-389; 2018; DOI.org/10.1016/j.jclepro.2018.08.042.

[7] D. Battini, M. Bogataj and A. Choudhary. "Closed Loop Supply Chain (CLSC): Economics, Modelling, Management and Control," International Journal of Production Economics, vol. 183, pp. 319-321, 2017; DOI:10.1016/j.ijpe.2016.11.020.

[8] D. Osborne, G. Smith and B. Mann. "Supply chain management for bulk materials in the coal industry In: D. Osborne, ed., The coal handbook. Toward cleaner production," Chapter 18, Philadelphia: Cambridge: Woodhead Publishing, 2013, pp. 589-627.
[9] D. Szczygielska. Wykorzystanie minerałów antropogenicznych w gospodarce obiegu zamkniętym, In: T. Szczygielski, ed., Minerały antropogeniczne a gospodarka o obiegu zamkniętym, Circular Economy, Warszawa: Politechnika Warszawska: Instytut Badań Stosowanych, 2015, pp.1732.

[10] E. Agora and Sandbag. "The European Power Sector in 2017. State of Affairs and Review of Current Developments 2018." Internet: https://sandbag.org.uk/wp-content/uploads/2018/01/EU-power-sector-report-2017 [Jun. 29.2018].

[11] E. Kukulska-Zając and M. Dobrzańska. „Zarządzanie odpadami wydobywczymi w świetle najnowszych uregulowań prawnych," Nafta-Gaz, vol. 12, pp. 1183-1189, 2012.

[12] E. Masoudipour, H. Amirian and R. Sahraeian. "A novel closed-loop supply chain based on the quality of returned products," Journal of Cleaner Production, vol. 151, pp. 344355, 2017; DOI: 10.1016/j.jclepro.2017.03.067.

[13] E. Włodarczyk and A. Rybak. "Organization of coal distribution in PGG," CBU International Conference Proceedings, 2018, 6, pp. 496-502.

[14] Energy security strategy. (2019). Available: https://ec.europa.eu/energy/en/topics/energy-strategy-and-energyunion/energy-security-strategy [Jun. 20.2019].

[15] Energy strategy and energy union. Secure, competitive, and sustainable Energy. (2019). Available: https://ec.europa.eu/energy/en/topics/energy-strategy-and-energyunion [Jun. 20.2019].

[16] Energy supply and energy security. (2016). Briefing Public expectations and EU policies, European Parlament, Bruksels. Available: http://www.europarl.europa.eu/thinktank/en/document.html?reference=EPRS_BRI(2018)630275. [Jun. 20.2019].

[17] European Commission. (2019), Development of a guidance document on best practices in the Extractive Waste Managements Pans. Circular Economy Action, Luxemburg: Eco Efficiency, pp. 1-46; DOI: 10.2779/061825. Available: https://ec.europa.eu/environment/waste/mining/pdf/guidance_extractive_waste. [Jun. 20.2019].

[18] European Commission. Assessment of Member States' performance regarding the implementation of the Extractive Waste Directive: appraisal of implementation gaps and their root causes, identifications of proposals to improve the implementation of the Directive. Final Report, Amec Foster Wheeler Environment \& Infrastructure UK Ltd, BiPRO and Milie Brussels: Luxembourg: Publications Office of the European Union, 2017, pp. 1-201, DOI: $10.2779 / 278202$.

[19] G. Kannan, H. Soleimani and D. Kannanc. "Reverse logistics and closed-loop supply chain: A comprehensive review to explore the future," European Journal of Operational Research, vol. 240(3), pp. 603-626; 2015, DOI.org/10.1016/j.ejor.2014.07.012.

[20] GUS $(2013,2014)$. Rocznik statystyczny przemysłu, Warszawa.

[21] GUS (2015). Rocznik statystyczny przemysłu, Warszawa.

[22] GUS (2016). Rocznik statystyczny przemysłu, Warszawa.

[23] GUS (2017). Rocznik statystyczny przemysłu, Warszawa.

[24] H. Kopnina. "Energy Policy in the European Union: Renewable Energy and the Risks of Subversion," Governance and security issues of the European Union, vol. 1, pp. 167-184, 2016, DOI: 10.1007/978-94-6265-144-9_10.

[25] I. Baic. „Technologie zagospodarowania odpadów z górnictwa węgla kamiennego - wyniki projektu FORESIGHT OGWK," Annual Set the Environment Protection, vol. 15, pp. 1899-1918, 2013. 
[26] J. Bijańska, A. Kuzior, K. Wodarski. „Social Perception of Hard Coal Mining in Perspective of Region's Sustainable Development," Management Systems in Production Engineering, vol. 26(3), pp. 178-183, 2018; DOI: https://doi.org/10.1515/mspe-2018-0029.

[27] J. Coenen, R.E.C.M. van der Heijden and A.C.R. van Rie. "Understanding approaches to complexity and uncertainty in closed loop supply chain management: Past findings and future directions," Journal of Cleaner Production, vol. 201, pp. 1-13, 2018; DOI.org/10.1016/j.jclepro.2018.07.216.

[28] J. Kim, B.D. Chung, Y. Kang and B. Jeong. "Robust optimization model for closed-loop supply chain planning under reverse logistics flow and demand uncertainty," Journal of Cleaner Production, vol. 196, pp. 1314-1328, 2018; DOI: 10.1016/j.jclepro.2018.06.157.

[29] J. Wang, J. Zhang, and J. Li. "A Scheduling Model of Coal Supply Chain Based on Supply Chain Management (SCM)," American Journal of Industrial Engineering, vol. 2(1), pp. 15-20, 2014; DOI: 10.12691/ajie-2-1-4. 17

[30] J.M.C. Martí, J.S. Tancrez and R.W. Seifert. "Carbon footprint and responsiveness trade-offs in supply chain network design," International Journal Production Economics, vol.166, pp. 129-142, 2015; DOI:10.1016/j.ijpe.2015.04.016.

[31] J.Z. Wu, C.H. Santoso and J. Roan. "Key factors for truly sustainable supply chain management: An investigation of the coal industry in Indonesia," The International Journal of Logistics Management, vol. 28(4), pp. 1196-1217, 2017; DOI.org/10.1108/IJLM-07-2014-0103.

[32] K. Culkova, S. Khouri, M. Straka and A. Rosova. "Ecological and Economic Saving of Fly Ash Using as Geopolymer," Annual Set the Environment Protection, vol. 20, pp. 73-88, 2018.

[33] K. Żmijewski. (2019, Jun. 5). Polityka energetyczna Polski do 2030 r. Europejski Instytut Miedzi Cooper Alliance. [Online]. Available: https://leonardo-energy.pl/wp-content/uploads/2016/10/Polityka-energetyczna-Polski-do2030. [Jun. 21, 2019].

[34] M. Biehl, E. Prater and M.J. Realff. "Assessing performance and uncertainty in developing carpet reverse logistics systems," Computers Operations Research, vol. 34(2), pp. 443-463, 2007; DOI:10.1016/j.cor.2005.03.008.

[35] M. Gray, Ljungwaldh, L. Watson, and I. Kok. "Powering down coal. Navigating the economic and financial risks in the last years of coal power. Carbon Tracker 2018," Ochrona środowiska. Warszawa, GUS. Internet: https://www.carbontracker.org/wp- content/uploads/2018/11/CTI_Powering_Down_Coal_Report_Nov_2018-1.pdf [Nov. 29.2018].

[36] M. Olkiewicz, R. Wolniak and B. Ostapko. „The analysis of dependencies between extraction and resource consumption 2008-2014 on the example of Gliśno gravel pit," Mining Science, vol. 63 (4), pp. 801-812; 2018, DOI:10.24425/ams.2018.124976.

[37] M. Olkiewicz, R. Wolniak, M. Grebski and A. Olkiewicz. "Comparative Analysis of the Impact of the Business Incubator Center on the Economic Sustainable Development of Regions in USA and Poland," Sustainability, vol. 11(173), pp. 1-22, 2019; DOI:org/10.3390/su11010173.

[38] M. Talaei, B.F. Moghaddam, M.S. Pishvaee, A. BozorgiAmiri, and S. Gholamnejad. „A robust fuzzy optimization model for carbon-efficient closed-loop supply chain network design problem: a numerical illustration in electronics industry," Journal Cleaner Production, vol. 113, pp. 62673, 2016; DOI.org/10.1016/j.jclepro.2015.10.074.
[39] M. Zohal and H. Soleimani. "Developing an ant colony approach for green closed-loop supply chain network design: a case study in gold industry," Journal of Cleaner Production, vol. 133, pp. 314-337, 2016; DOI: 10.1016/j.jclepro.2016.05.091.

[40] M.T. Islam and N. Huda. "Reverse logistics and closed-loop supply chain of Waste Electrical and Electronic Equipment (WEEE)/E-waste: A comprehensive literature review," Resources, Conservation \& Recycling, vol. 137, pp. 48-75, 2018; DOI.org/10.1016/j.resconrec.2018.05.026.

[41] M.Y.N. Attari and A.E. Torkayesh. "Developing benders decomposition algorithm for a green supply chain network of mine industry: case of Iranian mine industry," Operations Research Perspectives, vol. 5, pp. 371-382; 2018. DOI: 10.1016/j.orp.2018.11.002.

[42] N.M. Modak, N. Modak, S. Panda and S.S. Sana. „Analyzing structure of two-echelon closed-loop supply chain for pricing, quality and recycling management," Journal of Cleaner Production, vol. 171, pp. 512-528, 2018, DOI: 10.1016/j.jclepro.2017.10.033.

[43] Ochrona środowiska. (2018). Warszawa, GUS. Available: https://www.carbontracker.org/wp-content/uploads/2018/11/CTI_Powering_Down_Coal_Report_Nov_2018-1. [Jun. 20.2019].

[44] P. Benalcazar, J. Kamiński and P.W. Saługa. „The storage location problem in a coal supply chain: background and methodological approach," Gospodarka Surowcami Mineralnymi, vol. 33(1), pp. 5-14, 2017.

[45] P.Yi. Huang, M. Guo and T. Shi. "Dual recycling channel decision in retailer oriented closed-loop supply chain for construction machinery remanufacturing," Journal of Cleaner Production, vol. 137, pp. 1393-1405, 2016; DOI: 10.1016/j.jclepro.2016.07.104.

[46] Polityka energetyczna Polski do 2030 roku. (2009). Ministerstwo Gospodarki, Załącznik do uchwały nr 202/2009 Rady Ministrów, Warszawa. Available: http://www.pigeor.pl/media/js/kcfinder/upload/files/Polityka-energetyczna-Polski-do-2030 r. [Jun. 21, 2019].

[47] Polityka energetyczna Polski do 2040 roku (PEP2040). (2018). Ministerstwo Energi, Projekt Warszawa. Available: https://www.gov.pl/documents/33372/436746/PEP2040_projekt_v12_2018-1123.pdf/ee3374f4-10c3-5ad8-1843-f58dae119936. [Jun. 20.2019].

[48] Polska Izba Ekologii. (2014). Odpady i rekultywacja terenów poprzemysłowych, zwłaszcza pogórniczych. Prawo. Technologie. Available: http://www.pie.pl/konferencje/odpady-i-rekultywacja-terenow-poprzemyslowychzwlaszcza-pogorniczych-prawo-techn.html [Jun. 20.2019].

[49] R. He, Y. Xiong, and Z. Lin. "Carbon emissions in a dual channel closed loop supply chain: the impact of consumer free riding behavior," Journal of Cleaner Production, vol. 34, 384-394, 2016; DOI: 10.1016/j.jclepro.2016.02.142. 29

[50] R. He. "Supply risk sharing in a closed-loop supply chain," International Journal of Production Economics, vol. 183, pp. 39-52, 2017, DOI: 10.1016/j.ijpe.2016.10.012.

[51] R. Zuńiga, T. Wuest and K.D. Thoben. "Comparing mining and manufacturing supply chain processes: challenges and requirements," Production Planning \& Control, pp. 1-16, 2013; DOI.org/10.1080/09537287.2013.855335.

[52] Rozporządzenie Ministra Środowiska z dnia 9 grudnia 2014 r. w sprawie katalogu odpadów (2014). (Dz.U. 2014 poz. 1923). [On-line]. Available: http://prawo.sejm.gov.pl. [Jun. 21, 2019]. 
[53] S. Mhlanga, C. Mbohwa and J.H.C. Pretorius. "Transportation Demand Analysis of Coal from Hwange Coal Fields," Proceedings of the World Congress on Engineering, vol. 1, pp. 1-6, 2013.

[54] T. Olkuski. "Sposoby poprawy negatywnego skutku oddziaływania węgla na środowisko przyrodnicze poprzez stosowanie alternatywnych metod jego wykorzystania," Annual Set the Environment Protection, vol. 15, pp.1474-1488, 2013.

[55] S. Kołodziej, E.W. Maruszewska., Economical effectiveness and social objectiveness in corporate social reports - a survey among Polish publicly traded companies. $2^{\text {nd }}$ International Multidisciplinary Scientific Conference on Social Sciences and Arts SGEM2015, SGEM2015 Conference Proceedings, Book 2, Vol. 2, pp. 161-168.

\section{Joanna Dyczkowska \\ ORCID ID: 0000-0001-9866-3897 \\ Koszalin University of Technology \\ ul. Śniadeckich 2, 75-453 Koszalin, Poland}

\section{Yuliia Bulhakova}

ORCID ID: 0000-0001-8098-2443

Poznan University of Economics and Business Aleja Niepodległości 10, 61-875 Poznań, Poland e-mail: yuliia.bulhakova@ue.poznan.pl

\section{Zygmunt Łukaszczyk}

ORCID ID: 0000-0003-2370-1507

Silesian University of Technology, Faculty of Organization and Management ul. Roosevelta 26, 41-800 Zabrze, Poland e-mail: zygmunt.lukaszczyk@polsı.pl

\section{Anna Maryniak}

ORCID ID: 0000-0002-1344-671X

Poznań University of Economics and Business Aleja Niepodległości 10, 61-875 Poznań, Poland e-mail: anna.maryniak@ue.poznan.pl
[56] T. Shimada and L.N. Van Wassenhove. "Closed-Loop supply chain activities in Japanese home appliance/personal computer manufacturers: A case study," International Journal of Production Economics, vol. 212, pp. 250-256, 2019; DOI: 10.1016/j.ijpe.2016.11.010. 